\title{
PENGARUH PEMBERIAN LARUTAN SARI KURMA (PHOENIX \\ DACTYLIFERA L.) DAN LARUTAN FLUOR TERHADAP KEKERASAN EMAIL GIGI SETELAH DIRENDAM DALAM MINUMAN RINGAN BERKARBONASI
}

\author{
Mety Dwi Putri Eszy ${ }^{1}$, Afriwardi ${ }^{2}$, Susi $^{1}$ \\ ${ }^{1}$ Fakultas Kedokteran Gigi Universitas Andalas \\ ${ }^{2}$ Fakultas Kedokteran Universitas Andalas
}

\begin{abstract}
Soft drink with low $\mathrm{pH}(5,5)$ causes tooth erosion. Erosion may result in a decrease in surface hardness of tooth enamel. This research will be used a solution of palm juice and solution of fluoride to increase the surface hardness of tooth enamel. The purpose of this study was to evaluate effect of using a solution of palm juice 100\%, 75\%, 50\%, 25\% and APF 1,23\% to the surface hardness of tooth enamel. The methode used in this research is the experimental laboratory and were tested for their hardness using Vicker Hardness Tester.Measurement performed three times, initial hardness, after all specimens was soaked in soft drink for 25 hours and were then applied with 100\%, 75\%, 50\%, 25\% solution of palm juice dan APF 1,23\%. Data was analyzed by using SPSS with Repeated ANOVA.The result showed that a significant decrease in tooth enamel hardness on immersion in carbonated soft drink $(p<0,05)$ and increased hardness of surface enamel after application with $100 \%$ solution of palm juice with a mean increase of microhardness $42,91 \mathrm{VHN}, 38,46 \mathrm{VHN}$ with $75 \%$ solution of palm juice, 35,836 VHN with 50\% solution of palm juice,29,41 VHN with $25 \%$ solution of palm juice dan 23,94 VHN in APF 1,23\%.The result of this study is there is no significant difference enamel hardness after applied with 100\%, 75\%, 50\%, $25 \%$ solution of palm juice and APF 1,23\%.
\end{abstract}

Keywords: soft drink, erosion, surface tooth enamel hardness, solution of palm juice, APF

Affiliasi penulis: ${ }^{1}$ Fakultas Kedokteran Gigi Universitas Andalas Korespondensi: susi, email: susi@dent.unand.ac.id

\section{PENDAHULUAN}

Perkembangan globalisasi telah menyebabkan terjadinya perubahan gaya hidup. Salah satunya ditandai dengan peningkatan kebiasaan mengonsumsi minuman ringan oleh sebagian besar masyarakat di dunia. Hal ini terbukti dengan terjadinya peningkatan penjualan minuman ringan pada sepuluh tahun terakhir yaitu lebih dari $56 \%$ dan diperkirakan akan terus meningkat dalam 2-3 tahun ${ }^{1,2}$. WHO dan FAO Expert Consultation dalam laporan kesehatan diet, nutrisi dan penyakit kronik menemukan bahwa terdapat hubungan antara mengonsumsi minuman ringan dengan resiko terjadinya erosi gigi. Sebanyak $77 \%$ dokter gigi melaporkan kasus erosi gigi yang ditemui sebagian besar berhubungan dengan pola konsumsi masyarakat terutama kebiasaan dalam mengonsumsi minuman ringan. Beberapa penelitian menunjukkan bahwa anak-anak maupun dewasa merupakan kelompok yang beresiko mengalami erosi gigi $^{3}$. Erosi gigi ditandai dengan larutnya kristal hidroksiapatit, dimulai dari bagian terluar gigi yaitu email. Email gigi pada pH 7,4 cenderung stabil. Email akan 
bereaksi jika gigi terekspos oleh asam dengan $\mathrm{pH}$ yang rendah terutama dengan $\mathrm{pH}$ di bawah 5,5 yang memicu terjadinya demineralisasi ${ }^{4}$. Permukaan yang licin dan mengkilat akibat pelepasan sebagian struktur email merupakan tanda klinis yang ditemui pada gigi yang mengalami erosi. Apabila proses ini berlanjut dapat menyebabkan kehilangan sebagian dari prisma email dan akan terbentuk porositas pada gigi sehingga kekerasan pada permukaan email akan berkurang 5 .

Penyebab erosi dapat berasal dari faktor intrinsik dan ekstrinsik. Faktor intrinsik dapat berhubungan dengan asam lambung seperti Gastroesophageal reflux dan eating disorder. Sedangkan faktor ekstrinsik berasal dari luar rongga mulut seperti obat-obatan, lingkungan, makanan dan minuman yang bersifat asam ${ }^{5,6}$. Jenis, konsentrasi asam, kandungan karbohidrat, $\mathrm{pH}$ dan kapasitas dapar yang terdapat dalam minuman ringan akan mempengaruhi kecepatan melarutnya email gigi ${ }^{7}$. Minuman ringan mempunyai aksi termodinamik yang tinggi dan $\mathrm{pH}$ yang rendah sehingga minuman ini tidak mudah dihilangkan dan dinetralisir oleh saliva. Penambahan fluor, kalsium, fosfor dari luar dapat digunakan untuk membantu menetralisir efek asam dan $\mathrm{pH}$ dari minuman ringan dan dapat memicu terjadinya remineralisasi. 5,8
Fluor merupakan salah satu unsur yang melimpah pada kerak bumi. Sejumlah kecil fluoride dapat meningkatkan ketahanan struktur gigi terhadap demineralisasi dengan cara berikatan dengan mineral email dan membentuk senyawa fluoroapatit ${ }^{9}$. Penggunaan fluor dalam kedokteran gigi dapat dibagi menjadi dua cara yaitu, secara sistemik dan topikal. Pemberian afluor secara sistemik dapat dilakukan dengan cara fluoridasi air minum, pemberian fluor melalui makanan atau dalam bentuk obat-obatan. Sedangkan penggunaan fluor secara topikal adalah dengan cara pengaplikasian fluor secara langsung pada gigi ${ }^{4}$.

Selain terapi fluor, bahan alami juga dapat digunakan sebagai alternatif untuk membantu remineralisasi gigi. Menurut WHO, $80 \%$ populasi di dunia telah menggunakan obat herbal atau bahan alamiah untuk menanggulangi masalah kesehatan. ${ }^{10}$ Salah satunya adalah dengan menggunakan sari kurma untuk membantu mengembalikan mineral penyusun gigi yang hilang atau larut. Pada beberapa penelitian menunjukkan bahwa zat yang terkandung dalam kurma dapat mencegah terjadinya kanker, diabetes, penyakit kardiovaskular dan melindungi gigi dari kerusakan. Efek perlindungan gigi ini didapatkan karena adanya kandungan mineral-mineral dalam 
kurma yang dibutuhkan untuk memperkuat gigi $^{11}$. Penelitian yang dilakukan oleh Al-Essa et al, menunjukkan bahwa 8 dari 10 orang yang mengonsumsi kurma setiap hari memiliki Oral Hygiene yang bagus ${ }^{12}$. Berdasarkan data-data di atas, penulis tertarik untuk mengamati perubahan kekerasan email setelah direndam dalam larutan sari kurma dengan konsentrasi yang berbeda dan larutan fluor yang sebelumnya telah direndam dalam minuman ringan terhadap kekerasan mikro email gigi.

\section{METODE}

Disain penelitian yang digunakan adalah pre test and post test experimental. Sampel pada penelitian ini adalah gigi premolar permanen yang sudah diekstraksi.

Sampel dalam penelitian berjumlah 25 buah dan terdiri atas 5 kelompok perlakuan. Terdiri dari:

a. Grup 1: Spesimen yang direndam dalam larutan sari kurma $100 \%$ dan sebelumnya telah direndam dalam minuman ringan berkarbonasi

b. Grup 2: Spesimen yang direndam dalam larutan sari kurma $75 \%$ dan sebelumnya telah direndam dalam minuman ringan berkarbonasi

c. Grup 3: Spesimen yang direndam dalam larutan sari kurma 50\% dan sebelumnya telah direndam dalam minuman ringan berkarbonasi

d. Grup 4: Spesimen yang direndam dalam larutan sari kurma $25 \%$ dan sebelumnya telah direndam dalam minuman ringan berkarbonasi

e. Grup 1: Spesimen yang direndam dalam APF 1,23\% dan sebelumnya telah direndam dalam minuman ringan berkarbonasi

Penelitian diawali dengan melakukan persiapan terhadap sampel dan pembuatan larutan sari kurma dengan konsentrasi 100\%, 75\%, 50\%, $25 \%$. Selanjutnya sampel direndam dalam box yang berisi minuman ringan kemudian dilakukan pengukuran kekerasan email dan sebelumnya telah dilakukan pengukuran kekerasan email gigi awal. Setelah itu, sampel direndam dalam larutan sari kurma 100\%, 75\%, $50 \%$, 25\% dan larutan fluor lalu dilakukan pengujian kekerasan permukaan email sampel.

Analisis univariat dilakukan untuk melihat distribusi frekuensi dari variabel independen (larutan sari kurma dengan konsentrasi $25 \%, 50 \%, 75 \%, 100 \%$ dan larutan fluor (APF 1,23\%)) dan variabel dependen (kekerasan permukaan email gigi). Analisis bivariat untuk mengetahui hubungan antara variabel independen dengan variabel dependen, dilakukan uji Repeated ANOVA dengan tingkat kepercayaan $95 \%$ 


\section{HASIL DAN PEMBAHASAN}

Hasil pengukuran kekerasan permukaan sebelum dan sesudah perendaman dalam minuman ringan berkarbonasi dan sesuah perendaman dalam larutan sari kurma dan larutan fluor pada sampel

Tabel 1. Rerata hasil Pengukuran Kekerasan Permukaan Email Gigi (VHN) Sebelum dan Sesudah Perendaman dalam Minuman Ringan Berkarbonasi

\begin{tabular}{|c|c|c|c|c|c|}
\hline \multirow{2}{*}{$\begin{array}{c}\text { Varia } \\
\text { bel }\end{array}$} & \multirow[b]{2}{*}{$\mathrm{n}$} & \multicolumn{2}{|c|}{$\begin{array}{c}\text { Kekerasan } \\
\text { (VHN) }\end{array}$} & \multirow{2}{*}{$\begin{array}{c}\text { Penuru } \\
\text { nan } \\
\text { Kekeras } \\
\text { an }\end{array}$} & \multirow{2}{*}{$\begin{array}{c}\% \\
\text { Penuru } \\
\text { nan } \\
\text { Kekeras } \\
\text { an }\end{array}$} \\
\hline & & $\begin{array}{c}\text { Sebel } \\
\text { um }\end{array}$ & $\begin{array}{c}\text { Sesud } \\
\text { ah }\end{array}$ & & \\
\hline $\begin{array}{l}\text { Group } \\
1\end{array}$ & 5 & 293,93 & 42,43 & 215,5 & $73,31 \%$ \\
\hline $\begin{array}{l}\text { Group } \\
2\end{array}$ & 5 & 286,99 & 34,80 & 252,19 & $87,87 \%$ \\
\hline $\begin{array}{l}\text { Group } \\
3\end{array}$ & 5 & 293,53 & 36,29 & 257,24 & $87,63 \%$ \\
\hline $\begin{array}{l}\text { Group } \\
4\end{array}$ & 5 & 297,73 & 38,80 & 258,93 & $86,96 \%$ \\
\hline $\begin{array}{l}\text { Group } \\
5\end{array}$ & 5 & 283,26 & 34,52 & 248,74 & $87,81 \%$ \\
\hline $\begin{array}{l}\text { Rata- } \\
\text { rata }\end{array}$ & $\begin{array}{l}2 \\
5\end{array}$ & 291,09 & 37,37 & 253,72 & $87,16 \%$ \\
\hline
\end{tabular}

Berdasarkan Tabel 1 diketahui bahwa rerata penurunan kekerasan tertinggi adalah 258,93 VHN dengan persentase penurunan tertinggi yaitu $87,87 \%$.

Tabel 2. Rerata Hasil Pengukuran Kekerasan Permukaan Email Gigi (VHN) Setelah Pengaplikasian Larutan Sari Kurma dan APF 1,23\%

\begin{tabular}{|c|c|c|c|c|c|c|}
\hline \multirow{2}{*}{$\begin{array}{l}\text { Vari } \\
\text { abel }\end{array}$} & \multirow[b]{2}{*}{$\mathbf{n}$} & \multicolumn{2}{|c|}{$\begin{array}{c}\text { Kekerasan } \\
\text { (VHN) }\end{array}$} & \multirow{2}{*}{$\begin{array}{c}\text { Perub } \\
\text { ahan } \\
\text { Keker } \\
\text { asan }\end{array}$} & \multirow{2}{*}{$\begin{array}{c}\% \\
\text { Perub } \\
\text { ahan } \\
\text { Keker } \\
\text { asan }\end{array}$} & \multirow{2}{*}{$\begin{array}{l}\text { Keke } \\
\text { rasan } \\
\text { Awal }\end{array}$} \\
\hline & & $\begin{array}{l}\text { Sebe } \\
\text { lum }\end{array}$ & $\begin{array}{l}\text { Sesu } \\
\text { dah }\end{array}$ & & & \\
\hline $\begin{array}{l}\text { Sari } \\
\text { Kur }\end{array}$ & 5 & $\begin{array}{c}43,4 \\
3\end{array}$ & $\begin{array}{c}85,3 \\
4\end{array}$ & 42,91 & $\begin{array}{c}101,1 \\
3 \%\end{array}$ & $\begin{array}{c}293,9 \\
3\end{array}$ \\
\hline
\end{tabular}

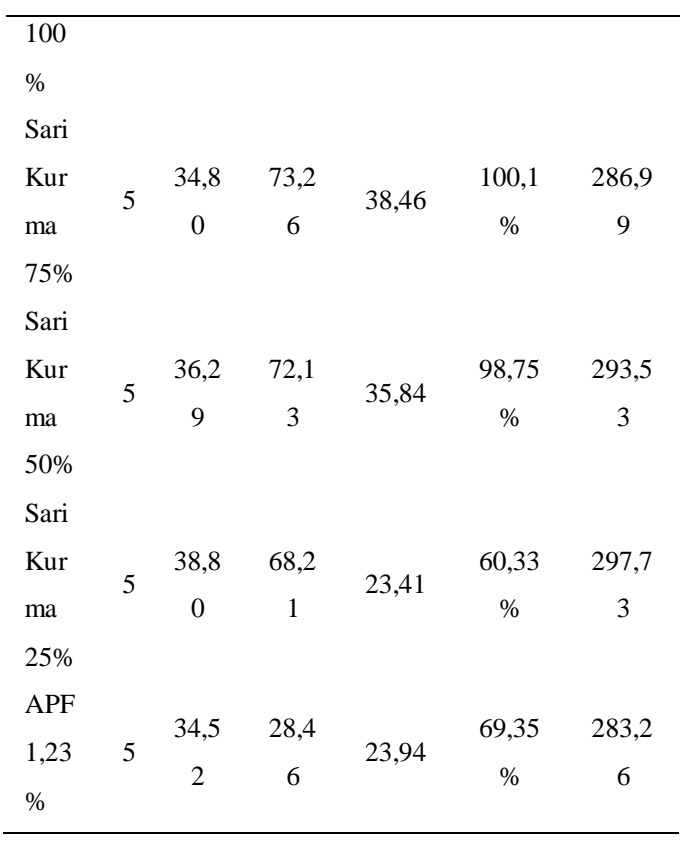

Berdasarkan Tabel 2 diketahui bahwa peningkatan kekerasan email gigi tertinggi setelah diaplikasikan larutan sari kurma dan fluor adalah 42,91 VHN dengan persentase peningkatan kekerasan yaitu $101,13 \%$.

Selanjutnya dilakukan uji statistik Repeated ANOVA untuk mengetahui apakah perbedaan kekerasan email gigi sebelum dan sesudah perendaman dalam minuman ringan berkarbonasi signifikan.

Tabel 3. Hasil Uji Statistik Rerata Hasil Pengukuran Kekerasan Permukaan Email Gigi (VHN) Sebelum dan Sesudah Perendaman dalam Minuman Ringan Berkarbonasi

\begin{tabular}{|c|c|c|c|c|}
\hline \multirow{2}{*}{$\begin{array}{c}\text { Variabe } \\
\text { l }\end{array}$} & \multirow[b]{2}{*}{$\mathbf{n}$} & \multicolumn{2}{|c|}{ Kekerasan (VHN) } & \multirow[b]{2}{*}{$p$} \\
\hline & & $\begin{array}{c}\text { Sebelum } \\
\text { Mean } \pm \text { SD }\end{array}$ & $\begin{array}{c}\text { Sesudah } \\
\text { Mean } \pm \text { SD }\end{array}$ & \\
\hline \multicolumn{5}{|l|}{ Larutan } \\
\hline Sari & 5 & $293.9300 \pm 45$ & $42.4380 \pm 5.5$ & \\
\hline Kurma & 5 & .43962 & 0276 & \\
\hline $100 \%$ & & & & 0,00 \\
\hline Larutan & & & & 0 \\
\hline Sari & 5 & $286.9960 \pm 28$ & $34.8040 \pm 4.6$ & \\
\hline Kurma & & .13756 & 4330 & \\
\hline $75 \%$ & & & & \\
\hline
\end{tabular}




\begin{tabular}{lccc} 
Larutan & & & \\
Sari & & $293.5300 \pm 25$ & $36.2980 \pm 7.0$ \\
Kurma & 5 & .30334 & 2859 \\
$50 \%$ & & & \\
Larutan & & & \\
Sari & 5 & $297.7300 \pm$ & $38.8060 \pm 5.3$ \\
Kurma & & 5.91600 & 8476 \\
$25 \%$ & & & \\
APF & & $283.2640 \pm 27$ & $34.5220 \pm 4.1$ \\
$1,23 \%$ & 5 & .64383 & 5185 \\
\hline Rata- & 2 & $291.0900 \pm 27$. & $337.3736 \pm 5$. \\
rata & 5 & 94156 & 80179 \\
\hline
\end{tabular}

Dari hasil analisa statistik diperoleh $\mathrm{p}=0,005 \quad(\mathrm{p}<0,05), \quad$ yang artinya data pada pengukuran sebelum dan sesudah perendaman dalam minuman ringan berkarbonasi memiliki perbedaan yang bermakna.

Tabel 4. Hasil Uji Statistik Rerata Hasil Pengukuran Kekerasan Permukaan Email Gigi (VHN) Sesudah Aplikasi Larutan Sari Kurma dan APF 1,23\%

\begin{tabular}{|c|c|c|c|c|}
\hline \multirow{2}{*}{$\begin{array}{c}\text { Variab } \\
\text { el }\end{array}$} & \multirow[b]{2}{*}{$\mathbf{n}$} & \multicolumn{2}{|c|}{ Kekerasan (VHN) } & \multirow[b]{2}{*}{$\mathbf{P}$} \\
\hline & & $\begin{array}{c}\text { Sebelum } \\
\text { Mean } \pm \text { SD }\end{array}$ & $\begin{array}{c}\text { Sesudah } \\
\text { Mean } \pm \text { SD }\end{array}$ & \\
\hline \multicolumn{5}{|l|}{ Laruta } \\
\hline $\begin{array}{l}\text { n Sari } \\
\text { Kurma }\end{array}$ & 5 & $\begin{array}{c}37.3736 \pm 5.80 \\
179\end{array}$ & $\begin{array}{c}85.3480 \pm 4.342 \\
52\end{array}$ & \\
\hline \multicolumn{5}{|l|}{$100 \%$} \\
\hline \multicolumn{5}{|l|}{ Laruta } \\
\hline $\begin{array}{l}\text { n Sari } \\
\text { Kurma }\end{array}$ & 5 & $\begin{array}{c}42.4380 \pm 5.50 \\
276\end{array}$ & $\begin{array}{c}73.2640 \pm 9.314 \\
33\end{array}$ & \\
\hline \multicolumn{5}{|l|}{$75 \%$} \\
\hline Laruta & & & & 0,00 \\
\hline n Sari & 5 & $34.8040 \pm 4.64$ & $72.1340 \pm 7.844$ & 0 \\
\hline \multicolumn{5}{|l|}{$50 \%$} \\
\hline \multicolumn{5}{|l|}{ Laruta } \\
\hline n Sari & 5 & $36.2980 \pm 7.02$ & $68.2160 \pm 14.28$ & \\
\hline Kurma & & 859 & 872 & \\
\hline \multicolumn{5}{|l|}{$25 \%$} \\
\hline $\begin{array}{l}\text { APF } \\
1,23 \%\end{array}$ & 5 & $\begin{array}{c}38.8060 \pm 5.38 \\
476\end{array}$ & $\begin{array}{c}58.4640 \pm 12.24 \\
650\end{array}$ & \\
\hline
\end{tabular}

Dari hasil analisa statistik diperoleh $\mathrm{p}=0,000(\mathrm{p}<0,05)$, yang artinya ada nilai perbedaan yang bermakna antara data sebelum dan sesudah perendaman dalam larutan sari kurma dan larutan fluor.

Tabel 5. Selisih Nilai Kekerasan Mikro Email Setelah Aplikasi Larutan Sari Kurma dan APF 1,23\%

\begin{tabular}{lccc}
\hline \multicolumn{1}{c}{ Variabel } & n & Mean \pm SD & P \\
\hline Larutan Sari & 5 & $42.9100 \pm 3.23519$ & \\
Kurma 100\% & & & \\
Larutan Sari & 5 & $38.4600 \pm 6.24569$ & \\
Kurma 75\% & & & \\
Larutan Sari & 5 & $35.8360 \pm 5.94723$ & 0,093 \\
Kurma 50\% & 5 & & \\
Larutan Sari & 5 & $29.4100 \pm 18.96593$ & \\
Kurma 25\% & 5 & & \\
APF 1,23\% & 5 & $23.9420 \pm 12.73993$ & \\
\hline
\end{tabular}

Dari hasil analisa statistik diperoleh p>0,05 yaitu 0,093. Hal ini berarti bahwa tidak terdapat perbedaan yang bermakna dari rerata kekerasan email gigi setelah diaplikasikan larutan sari kurma 100\%, 75\%, 50\%, 25\% dan APF $1,23 \%$.

Kekerasan permukaan email gigi adalah besarnya kemampuan gigi untuk menahan beban yang mengenai permukaan gigi. Hasil penelitian yang telah dilakukan menunjukkan terjadi penurunan kekerasan email gigi akibat perendaman dalam minuman ringan berkarbonasi selama 25 jam. Pada penelitian ini nilai kekerasan email gigi berkisar antara 245,66-353 VHN dan tidak jauh berbeda dengan nilai kekerasan permukaan email gigi pada umumnya yaitu berkisar antara 270-350 KHN atau 250-360 VHN. Pada hasil penelitian yang telah dilakukan terjadi penurunan kekerasan permukaan email 
gigi setelah direndam dalam minuman ringan berkarbonasi menjadi 37,37 $\mathrm{VHN}^{13}$.

Penurunan kekerasan email gigi setelah direndam dalam minuman ringan berkarbonasi pada penelitian ini disebabkan karena terjadi kelarutan pada email gigi yang ditandai dengan rusaknya hidroksiapatit akibat proses kimia atau biasa disebut dengan demineralisasi. Demineralisasi akan terjadi apabila cairan disekitar email gigi berada pada $\mathrm{pH}$ asam. ${ }^{2}$ Pada $\mathrm{pH}$ yang rendah, konsentrasi ion hidrogen akan meningkat dan ion ini akan bereaksi dengan kristal apatit gigi sehingga kristal ini menjadi tidak stabil dan rusak. Penurunan kekerasan email gigi pada penelitian ini tidak hanya diakibatkan oleh $\mathrm{pH}$ minuman ringan yang rendah tapi juga dipengaruhi oleh kapasitas dapar, jenis dan kandungan asam yang terdapat dalam minuman ringan 2, 14 . Hasil penelitian ini juga didukung oleh penelitian yang dilakukan oleh Gedalia et al untuk melihat pengaruh coca-cola terhadap email gigi. Hasil penelitiannya menunjukkan bahwa setelah satu jam gigi terpapar oleh coca-cola terjadi penurunan kekerasan email gigi yang signifikan dan terdapat perubahan pada struktur permukaan email gigi ${ }^{15}$.

WK Seow dan KM Thong dalam penelitiannya juga menyebutkan adanya penurunan kekerasan email gigi sebanyak $24 \%$ setelah dilakukan perendaman dalam coca-cola selama 60 menit ${ }^{16}$. Pada penelitian yang dilakukan oleh Prasetyo pada gigi yang direndam dalam minuman cola selama 120 menit terjadi penurunan kekerasan email gigi yang sangat nyata dan bermakna ${ }^{14}$. Pada penelitian ini juga dilakukan pengukuran kekerasan email gigi setelah diaplikasikan larutan sari kurma dan APF 1,23\%. Hasil perhitungan Repeated ANOVA pada sampel setelah diaplikasikan larutan sari kurma dan APF $1,23 \%$ menunjukkan adanya peningkatan nilai kekerasan email gigi dengan $\mathrm{p}<0,05$ yaitu $\mathrm{p}=0,000$. Peningkatan nilai kekerasan email gigi ini disebabkan karena adanya kandungan kalsium, fosfor dan fluor dalam kurma.

Kalsium dan fosfor merupakan bagian dari kristal hidroksiapatit yang juga dapat meningkatkan kekerasan permukaan email dengan cara membentuk kembali struktur kristal penyusun email yang hilang atau larut. Selain kalsium dan fosfor, fluor yang terkandung dalam kurma juga mempengaruhi nilai kekerasan email gigi. Fluor dapat memperkuat interaksi antara kalsium dan fosfor dan mencegah kehilangan mineral yang lebih banyak akibat erosi dengan cara berikatan dengan kristal apatit membentuk fluoroapatit ${ }^{17,18}$. Pada penelitian yang 
dilakukan oleh Walid Al-Shahib and Richard J. Marshall menyebutkan kurma dapat mencegah terjadinya kerusakan gigi karena adanya kandungan mineral penyusun gigi yang terkandung di dalam kurma, salah satunya yaitu adanya kandungan fluor dalam kurma ${ }^{19}$. Pada sampel yang diaplikasikan APF 1,23\% juga terjadi peningkatan kekerasan email gigi. Hal ini disebabkan karena adanya kandungan fluor yang relatif tinggi. Pemberian fluor juga dapat berfungsi meningkatkan remineralisasi dengan cara mengubah lingkungan permukaan email, sehingga transfer ion ke email dapat berlangsung efektif. Hasil penelitian ini juga didukung oleh penelitian yang dilakukan oleh Sherine BY dan Mohamed yang menunjukkan APF dapat mengurangi dan melindungi gigi dari efek erosi ${ }^{20}$. Pada penelitian ini berdasarkan uji statistik tidak terdapat perbedaan peningkatan rerata nilai kekerasan email gigi yang signifikan antara sampel yang diaplikasikan dengan larutan sari kurma dan APF. Hal ini menunjukkan bahwa potensi larutan sari kurma untuk meningkatkan remineralisasi gigi hampir sebanding dengan penggunaan topikal aplikasi fluor.

\section{SIMPULAN}

1. Terjadi penurunan kekerasan email gigi yang bermakna setelah perendaman dalam minuman ringan berkarbonasi dengan selisih rerata penurunan kekerasan sebesar 253,72 VHN.

2. Terjadi peningkatan kekerasan email gigi pada sampel yang telah diaplikasikan larutan sari kurma $100 \%, 75 \%, 50 \%, 25 \%$ dan sebelumnya telah direndam dalam minuman ringan berkarbonasi yaitu pada konsentrasi $100 \%$ dari 42.43 VHN menjadi 85.34 VHN, pada konsentrasi $75 \%$ dari 34.80 VHN menjadi 73.26 VHN, pada konsentrasi $50 \%$ dari $36.29 \mathrm{VHN}$ menjadi 72.13 VHN, pada konsentrasi $25 \%$ dari $38.80 \mathrm{VHN}$ menjadi 68.21 VHN.

3. Terjadi peningkatan kekerasan email gigi pada sampel yang telah diaplikasikan APF $1,23 \%$ dan sebelumnya telah direndam dalam minuman ringan berkarbonasi yaitu dari 34.52 VHN menjadi 58.46 VHN.

4. Tidak terdapat perbedaan yang bermakna rerata peningkatan kekerasan email gigi antara larutan sari kurma 100\%, 75\%, 50\%, 25\% dan APF $1,23 \%$.

\section{KEPUSTAKAAN}

1. Maganur PDC, AR Prabhakar, Sugandhan S, Srinivas N. Evaluation of Microleakage of 
RMGIC and Flowable

Composite Immersed in Soft

Drink and Fresh Fruit Juice: An

in vitro Study. International

Journal of Clinical Pediatric

Dentistry 3(3): 153-161. 2010

2. Silaen DN dan Rehulina.

Kehilangan Material Enamel

pada Permukaan Bukal Premolar

Satu Akibat Perendaman

Minuman Bersoda (In Vitro).

Dentistry E-Journal. Vol 2,

No.1:39-48. 2013

3. Rangan A, Debra Hecter, Jimmy

Louie, Vicki Flood, Tim Gill.

Soft Drinks, Weight Satus and

Health. NS Centre for Public

Health Nutrition. 2009

4. Putri MH, Eliza H, Neneng N.

Ilmu Penyakit Jaringan Keras dan Jaringan Pendukung Gigi hal 163-189. Jakarta: EGC. 2011

5. Larsen M.J. Erosion of The Teeth. In (Ole Fejerskov and Edwina Kidd ed). Dental Caries: The Dissease and Its Clinical Management, 2nd Edition: 233246. Blackwell Munksgaard. 2008

6. Ren YF. Dental Erosion: Etiology, Diagnosis and Prevention. A Peer-Reviewed Publication. 2011

7. Mudumba VL, Radhika M, NCH Srnivas, Duddu MK. Evaluation and Comparison of Changes in Microhardness of Primary and Permanent Enamel on Exposre to Acidic Center-filled Chewing Gum: An in vitro Study. International Journal of Clinical Pediatric Dentistry 7(1):23-27. 2014

8. Madan N, Neeraj M, Vickram S, Deepak Pardal, Nidhi M. Tooth remineralization using bioactive glass- A novel approach. Journal of Academy of Advanced Dental Research. Vol 2. 2011

9. Abirani S and Dr. J. Sivabalan. Inceasing the Acid Resistance Against Dental Erosion Through Fluoride Therapy. SSRG International Journal of Applied Chemistry. Vol 1 No.39:88-92. 2014

10. Marzuki A, Nurhainun Ibrahim, Uslam. Pengaruh Pemberian Sari Kurma (Phoenix dactylifera L) Terhadap Perubahan Jumah Trombosit pada Tikus (Rattus Norvegicus). Majalah Farmasi dan Farmakologi. Vol 16, No.2:85-88. 2012

11. Al-Seeni MN. Minerals Content and Antimicrobial Efficacy of Date Extracts against Some Pathogenic Bacteria. Life Science Journal 9(2): 117-127. 2012 
12. Al-Essa NA, Manal A Al Mutairi, Hadell M Al Ohali, Ahmed EH, Arham C. Caries, Oral Hygiene Status and Dates Consumption Among Saudi Female University Students. International Research Presentation. Vol.2 (5): 1-10. 2007

13. Salazar MPG and Jorge RG. Microhardness and Chemical Composition of Human Tooth. Material Research. Vol 6, No.3:367- 373. 2003

14. Prasetyo EA. Keasaman minuman ringan menurunkan kekerasan permukaan gigi. Majalah Kedokteran Gigi (Dental Journal). Vol 38, No.2:60-63. 2005

15. El-Zainy MA, Ahmed $\mathrm{MH}$, Amany AR. The Effect of Some Carbonated Beverages on Enamel of Human Premolars (Scanning and Light Microscopic Study). Journal of American Science.Vol 8, No.3:632-643. 2012

16. Seow WK and KM Thong. Erosive effect of commonbeverages on extracted premolar teeth. Australian Dental Journal 50(3): 173-178. 2005
17. Madan N, Neeraj M, Vickram S, Deepak Pardal, Nidhi M. Tooth remineralization using bioactive glass- A novel approach. Journal of Academy of Advanced Dental Research. Vol 2. 2011

18. Walsh LJ. Contemporary technologies for remineralization therapies: A review. International Dentistry SA. 2010. Vol 11, No.6.

19. Hemagaran $\mathrm{P}$ and Prasanna N. Remineralization of the tooth structure-the future of dentistry. International Journal of PharmTech Research. Vol 6, No.2:487- 493. 2014

20. BY Badr S and Mohamed AI. Protective effect of three different fluoride pretreatments on artificially induced dental erosion in primary and permanent teeth. Journal of Americans Science. Vol 6, No.11:442-449.2010 